\author{
양념 돈육의 $10^{\circ} \mathrm{C}$ 숙성시 품질변화 \\ 진상근*. 김일석*. 하경희**.류현지**. 박기훈*. 이정일***. 정구용***** \\ 진주산업대학교 동물소재공학과*, 농촌진흥청 축산연구소**, 경상남도 첨단양돈연구소***, \\ 상지대학교 생명자원과학대학 동물자원학과****
}

\title{
Changes of Quality Characteristics of Seasoned Pork during Aging at $10^{\circ} \mathrm{C}$
}

\author{
S. K. Jin*, I. S. Kim*, K. H. Hah**, H. J. Lyou**, K. H. Park*, J. I. Lee*** and K. Y. Chung**** \\ Department of Animal Resources Technology, Jinju National University*, \\ National Livestock Research Institute**, Advanced Swine Research Institute, Gyeongnam Province***, \\ Department of Animal Science and Technology, College of Life Science and Natural Resources, \\ Sangji University****
}

\begin{abstract}
This study was conducted to investigate the changes of quality characteristics on seasoned pork with Korean traditional 4 types seasoning such as soybean sauce (T1); Kimchi sauce (T2); pickled shrimps sauce (T3); onion sauce (T4). The seasoned samples were aged at $10 \pm 1{ }^{\circ} \mathrm{C}$ for 13 days. The results obtained were as follows; Except for $\mathrm{T} 2, \mathrm{pH}$ of treatments were significantly decreased $(\mathrm{P}<0.05)$ as aging period increased. Salinity (\%) and saccharinity (\%) of seasoned meat were tended to increased during aging period. Thiobarbituric acid reactive substances (TBARS) were increased significantly during storage in all treatment $(\mathrm{P}<0.05)$. T4 showed the highest TBARS among the all treatment groups. Volatile basic nitrogen $(\mathrm{VBN})$ values of all treatments were significantly increased $(\mathrm{P}<0.05)$ as storage period increased. There were no significant differences in water holding capacity (WHC) among the all treatments, and those values were not changed by the passage of storage days. Shear force values of all treatments were tended to decreased by the passage of storage days. In surface color, the values of $\mathrm{L}^{*}, \mathrm{a}^{*}$ and $\mathrm{b}^{*}$ showed a tendency of increasing value along the storage days. The values of $\mathrm{a}^{*}$ and $\mathrm{b}^{*}$ of $\mathrm{T} 2$ were significantly higher than other treatments during aging period $(\mathrm{P}<0.05)$. In inner color, $\mathrm{a}^{*}$ and $\mathrm{b}^{*}$ values of $\mathrm{T} 2$ were significantly higher than those of other treatments during aging period $(\mathrm{P}<0.05)$. In the sensory evaluation of cooked meat, T3 treatment resulted in lower score in aroma, flavor, tenderness, juiciness and overall acceptability. The number of total plate counts and Lactobacilli spp. tended to increase with storage in all treatments group. The numbers of Escherichia coli were not changed by the passage of storage time.
\end{abstract}

(Key words : Quality characteristics, Seasoned pork, Aging)

$\begin{array}{cl}\text { I. 서 론 } & \begin{array}{c}\text { 가 있겠지만 특히 양념 없이 구워먹을 시에는 } \\ \end{array} \\ \text { 삼겹살과 목심 부위에 비하여 상대적으로 지방 } \\ \text { 국내 소비자들이 지방이 적은 돼지고기 비선 } & \text { 함량이 적기 때문에 퍽퍽하고 단단하며 다즙성 } \\ \text { 호 부위육을 먹기 꺼려하는 이유는 여러 가지 } & \text { 이 없어 기호성이 낮기 때문이다. 이러한 문제 }\end{array}$

Corresponding author:I. S. Kim, Department of Animal Resources Technology, Jinju National University, Jinju, 660-758, Korea. Tel : 82-55-751-3288, Fax : 82-55-758-1892, E-mail : iskim @jinju.ac.kr 
점을 해결하고 소비를 촉진하고자 많은 노력들 을 하고 있다. 주로 간장과 고추장을 이용하는 발효 숙성육은 자가 숙성에 의하여 이루어지며 이에 의하여 근육 단백질이 연화되고 또한 유 리아미노산, 핵산관련물질, 아민류, 암모니아, 크레아틴 등 비단백태 질소화합물이 증가하여 육의 독특한 맛과 향을 내게 된다(Dierick 등, 1974). 양념은 음식물의 맛과 냄새를 좋게 하고 입맛을 돋우며 소화를 촉진시키는데서 중요한 역할을 한다. 양념은 음식물에 소량이 들어가 지만 영양가를 높여줌과 동시에 사람의 몸 안 에서 생리활성 효과를 나타내므로 건강을 향상 시키는데 일정한 작용을 하며, 양념육에 사용 되는 양념류는 통상 악취 제거뿐만 아니라 연 화작용으로 소화 흡수를 도와주는 역할을 하는 것으로 알려져 있다(Moon 등, 1991).

전통 양념인 간장, 김치, 새우젓 및 양파 소 스는 오래 전부터 식생활에 중요한 기본양념으 로 널리 이용되어 왔으며, 그 중에서 간장은 향미 증진제로 사용하고 있으며 대두의 느린 발효과정에 의하여 만들어진다. 간장의 구성성 분인 소금, 아미노산 설탕, 산, 방향성 에스테 르와 열처리 과정에서 발생하는 다른 성분들은 독특한 맛과 향을 생성하는데 기여를 하고 자 연적인 향미 증진을 촉진시킨다. 김치는 비타 민과 미네랄을 많이 함유하며, 특히 비타민 $\mathrm{C}$ 와 $\mathrm{Ca}$ 이 많이 들어 있으며 항암효과, 독성물질 제거 효과 및 항돌연변이 효과가 있다(허, 1996). 새우젓에는 단백질 $16 \%$, 탄수화물 15.4 $\%$, 무기질이 $9.9 \%$ 로 그 중에서도 칼슘과 인이 많이 포함되어 있으며, 독특한 향을 나타내는 성분들이 존재한다(차, 1995). 또한 IMP 등의 핵산관련 분해물들과 glutamic acid 등의 정미성 분들이 다량 함유되어 있어 감칠맛을 낸다(정 과 이, 1976). 특히 새우젓에는 강력한 단백질 분해효소가 존재하는 것으로 알려져 있으며(박 과 주, 1986), 이 효소는 가열처리한 식육에 더 욱 강력하게 작용하는 것으로 알려져 있다(오 등, 1997). 양파에는 생리활성물질인 flavonoid 계통의 물질인 quercetin, myricetin, rutin 등이 함유되어 있어 항염( $\mathrm{Kim}$ 등, 1990), 혈압강하, 살충작용(柴田承二 등, 1970), 암 예방, 고혈압
예방 및 당뇨병 치료에 효과가 있는 것으로 알 려지고 있다(Stavric 등, 1992). 특히 양파 내의 quercetin이나 rutin 등은 항산화력을 갖는 물질 로 알려져 있으며(Silvia 등, 1984; Toshimitsu 등, 1988), 항균효과에 의한 식품보존 효과가 있는 것으로 밝혀져 있다(Zohri 등, 1995). 한편 전통장류의 생리활성 기능에 관한 연구로 장류 의 항암효과, 콩의 생리활성 물질, 장류의 신 색소의 기능성, 청국장의 혈전 용해 기능 및 된장의 면역 증강 물질 등에 관한 연구들이 진 행되어 왔다(김 등, 1999).

최근 양념 등을 이용한 연구 경향을 보면 돼 지 뒷다리 육에 전통 장류인 간장을 첨가하여 제조한 양념육에 관한 연구(Kim 등, 1998), 양 념한 돼지고기의 냉장 중 품질변화에 관한 연 구(최와 이, 2002), 한국 전통 양념을 이용한 발 효 돼지고기의 품질특성 연구(진 등, 2004)와 전통양념으로 숙성하여 진공포장한 돼지고기의 저장 중 품질 변화(진 등, 2005b) 등의 연구가 수행되어져 왔다.

본 연구는 한국인들의 입맛에 맞는 전통 양 념류에 돼지고기 뒷다리 부위를 침지하여 숙성 시키는 동안 물리화학적인 품질특성을 파악하 고 산업화를 위한 기초 자료를 제시함으로써 궁극적으로 돼지고기 비선호부위의 소비확대 방안을 모색하고자 실시하였다.

\section{II. 재료 및 방법}

\section{1. 공시재료 및 양념 배합비}

돼지를 도축 후 24시간 냉각된 지육 중에서 농림부가 고시한 가공기준에 준하여 뒷다리 부 위 중 바깥 볼깃살을 채취하여 과다한 지방을 제거하였다. 준비한 시료들을 $7 \times 10 \times 2 \mathrm{~cm}^{3}$ 크 기로 자른 후 Table 1 과 같은 배합비의 양념액 과 육의 비율을 $1: 1$ 로 하여 침지한 후 실제 유 통 시 온도변화에 대한 악조건을 시험하기 위 하여 식품공전상 냉장온도의 최고 온도인 $10 \pm$ $1{ }^{\circ} \mathrm{C}$ 의 냉장고에 넣고 13 일간 발효·숙성시키면 서 실험 재료로 공시하였다. 단, 최종 양념액의 염도와 당도는 각각 $3.0,30$ 으로 맞추었다. 품 
Table 1. Formula of Korean traditional seansonings containing soy sauce, Kimchi, shrimps and onion

\begin{tabular}{|c|c|c|c|c|}
\hline Ingredients & $\begin{array}{c}\mathrm{T} 1 \\
\text { (Soy base) }\end{array}$ & $\begin{array}{c}\mathrm{T} 2 \\
\text { (Kimchi base) }\end{array}$ & $\begin{array}{c}\mathrm{T} 3 \\
\text { (Pickled shrimps base) }\end{array}$ & $\begin{array}{c}\mathrm{T} 4 \\
\text { (Onion base) }\end{array}$ \\
\hline Pickled shrimp & & 2.5 & 12 & \\
\hline Garlic & 10 & & 11 & 15 \\
\hline Corn Syrup & 27 & 33 & 30 & 28 \\
\hline Ginger & 1 & & 3 & 8 \\
\hline Red pepper & 1 & & 2 & 3 \\
\hline Green onion & & & 9.5 & \\
\hline Sesame & & & 0.5 & \\
\hline Sesame oil & 0.5 & & & \\
\hline Red pepper (p) & & 1 & 0.5 & \\
\hline Water & 14.5 & 5.5 & 31.5 & 6.2 \\
\hline Onion & 10 & 13 & & 20 \\
\hline Salt & & 2 & & 2.8 \\
\hline Vinegar & & & & 2 \\
\hline Radish & 5 & & & 3 \\
\hline Ethyl alcohol & & 3 & & 2 \\
\hline Pineapple & 10 & 10 & & 10 \\
\hline Kimchi & & 30 & & \\
\hline Soy sauce & 21 & & & \\
\hline Total & 100 & 100 & 100 & 100 \\
\hline
\end{tabular}

질 측정 시 표면에 묻어 있는 양념은 흐르는 물로 한 번 씻은 후 물기를 닦아낸 다음 품질 측정에 이용하였다.

\section{2. 분석항목 및 분석방법}

\section{(1) $\mathrm{pH}$}

근막, 지방 등을 제거한 후 세절한 시료육 $10 \mathrm{~g}$ 을 증류수 $90 \mathrm{ml}$ 와 함께 homogenizer(IKA, T25 Basic Malaysia)로 $13,500 \mathrm{rpm}$ 에서 10초간 균질하여 $\mathrm{pH}$-meter(Orion 230A, USA)로 측정하 였다.

(2) 염도

시료와 소스의 염도는 일정량 희석하여 Quantab(USA)의 chloride titrators의 방법으로 측 정하였다.

(3) 당도
시료와 소스의 당도는 일정량 희석하여 당도 계(ATAGO PR-101, Japan)로 측정하였다.

\section{(4) TBARS}

Buege와 Aust(1978)의 방법에 의해 시료 $5 \mathrm{~g}$ 에 butylated hydroxyanisole(BHA) $50 \mu$ 와 증류수 $15 \mathrm{ml}$ 을 첨가하여 균질화 시킨 후 균질액 $1 \mathrm{ml}$ 을 시험관에 넣고 여기에 $2 \mathrm{ml}$ thiobarbituric acid(TBA)/trichloroacetic acid(TCA) 혼합용액을 넣어 완전히 혼합한 다음, $90^{\circ} \mathrm{C}$ 의 항온수조에 서 15 분간 열처리한 후 냉각시켜 $3,000 \mathrm{rpm}$ 에서 10 분간 원심분리시켰다. 원심분리한 시료의 상 층을 회수하여 $531 \mathrm{~nm}$ 에서 흡광도를 측정하였 다.

$$
T B A R S=\text { 흡광도 수치 } \times 5.88
$$

(5) VBN

高坂(1975)의 방법을 이용하여 세절육 $10 \mathrm{~g}$ 에 
증류수 $90 \mathrm{ml}$ 를 가하여 균질한 후 균질액을 whatman No. 1로 여과하여 여과액 $1 \mathrm{ml}$ 를 conway unit 외실에 넣고 내실에는 $0.01 \mathrm{~N}$ 붕산 용액 $1 \mathrm{ml}$ 와 지시약 $(0.066 \%$ methyl red $+0.066 \%$ bromocresol green)을 3방울 가하였다. 뚜껑과의 접착부위에 glycerine을 바르고 뚜껑을 닫은 후 $50 \% \mathrm{~K}_{2} \mathrm{CO}_{3} 1 \mathrm{ml}$ 를 외실에 주입 후 즉시 밀폐 시킨 다음 용기를 수평으로 교반한 후 $37^{\circ} \mathrm{C}$ 에 서 120 분간 배양하였다. 배양 후 $0.02 \mathrm{~N} \mathrm{H}_{2} \mathrm{SO}_{4}$ 로 내실의 붕산용액을 측정하였다.

(6) 보수력

마쇄한 시료를 $70^{\circ} \mathrm{C}$ 의 항온수조에서 30 분간 가열한 다음 냉각하여 $1,000 \mathrm{rpm}$ 에서 10 분간 원 심분리한 후 무게를 측정하여 전수분에 대한 백분율로 계산하였다.

\section{(7) 전단가}

조직감은 Rheometer(EZtest, shimadze, Japan) 를 이용하여 shearing cutting test로 측정하였으 며, 이때의 분석조건은 chart speed $120 / \mathrm{mm} / \mathrm{min}$, maximum load $10 \mathrm{~kg}$, 측정속도 $20 \mathrm{~mm}$, 시료높 이 $20 \mathrm{~mm}$, adapter No. 4 로 측정하였다.

(8) 육색

표면 육색은 고기의 표면에 묻어 있는 소스 를 칼 등으로 제거한 다음 chromameter(Minolta Co. CR 301, Japan)를 이용하여 동일한 방법으 로 5 회 반복하여 측정하였으며, 심부 육색은 고기를 절단하여 그 단면을 표면 육색과 동일 한 방법으로 측정하여 명도(lightness)를 나타내 는 $\mathrm{L}^{*}$ 값, 적색도(redness)를 나타내는 $\mathrm{a}^{*}$ 값과 황 색도(yellowness)를 나타내는 $\mathrm{b}$ *값을 측정하였 다. 이때 표준색은 $\mathrm{L}^{*}$ 값이 $89.2, \mathrm{a}^{*}$ 값이 0.921 , $\mathrm{b}^{*}$ 값이 0.783 인 표준색판을 사용하여 표준화한 다음 측정하였다.

(9) 관능검사

관능검사는 잘 훈련된 관능검사요원 10 명을 선발하여 각 시험구별로 9점 척도법으로 관능 검사를 실시하였다. 신선육을 $100{ }^{\circ} \mathrm{C}$ 전기오븐 에서 가열하여 중심온도가 $74{ }^{\circ} \mathrm{C}$ 도달시 이용
하였다.

(10) 미생물

총균수는 시료 $10 \mathrm{~g}$ 을 $1 \%$ peptone수 $90 \mathrm{ml}$ 에 넣고 bagmixer로 균질시킨 다음 $1 \mathrm{ml}$ 를 채취하 여 준비된 $9 \mathrm{ml}$ peptone수에 넣어 희석한 후 희 석액을 미리 조제한 배지(plate counter agar, $\mathrm{Difco}$ )에 평판 배양하여 $32^{\circ} \mathrm{C}$ 에서 2 일 배양한 후 colony를 계수하였다. 대장균(E. coli)은 희석 액을 MaCConkey agar에 평판 배양하여 $37^{\circ} \mathrm{C}$ 에 서 1일 배양한 후 colony를 계수하였으며, 유산 균은 희석액을 MRS agar에 평판 배양하여 30 ${ }^{\circ} \mathrm{C}$ 에서 2일 배양한 후 colony를 계수하였다.

\section{3. 통계처리}

이상의 실험에서 얻어진 결과는 $\mathrm{SAS}(1999)$ 의 GLM(General Linear Model) 방법으로 분석하였 고, 처리 평균 간의 비교를 위해 Duncan의 Multiple range test가 이용되었다.

\section{III. 결과 및 고찰}

\section{1. 전통 양념을 이용한 숙성 돼지고기의 $\mathrm{pH}$ 변화}

전통 양념을 이용한 숙성 돼지고기의 $10^{\circ} \mathrm{C}$ 숙성 중 양념육의 $\mathrm{pH}$ 변화는 Table 2에 나타내 었다. $10^{\circ} \mathrm{C}$ 에서 숙성시킨 육의 $\mathrm{pH}$ 는 $\mathrm{T} 4$ 처리구 를 제외한 모든 처리구에서 저장기간이 경과함 에 따라 유의적으로 감소하였으며 $(\mathrm{P}<0.05)$, 처 리구 간의 비교에서는 저장 7 일까지는 $\mathrm{T} 4$ 처리 구가 다른 처리구에 비하여 유의적으로 낮았는 데 이는 양념액 배합 시 식초가 첨가되었기 때 문인 것으로 판단되며, 7일 이후에는 다른 처 리구에 비하여 유의적으로 높은 $\mathrm{pH}$ 를 보였다 $(\mathrm{P}<0.05)$. 이는 $\mathrm{T} 4$ 가 양파소스이기 때문에 다른 세 처리구들에 비하여 숙성 중 유산 등이 적게 생성되었기 때문으로 판단된다. 김치 소스로 처리한 $\mathrm{T} 2$ 처리구의 $\mathrm{pH}$ 변화가 가장 크게 나 타났는데 저장 말에는 4.31까지 감소하였으며 이는 발효에 의한 유산균의 증가에 따른 것으 
Table 2. Changes of $\mathrm{pH}$ of seasoned pork during aging at $10 \pm 1^{\circ} \mathrm{C}$

\begin{tabular}{|c|c|c|c|c|c|}
\hline \multirow{2}{*}{ Treatment $^{1)}$} & \multicolumn{5}{|c|}{ Storage(days) } \\
\hline & 1 & 4 & 7 & 10 & 13 \\
\hline $\mathrm{T} 1$ & $5.24 \pm 0.01^{\mathrm{Ba}}$ & $5.17 \pm 0.02^{\mathrm{Ba}}$ & $5.08 \pm 0.01^{\mathrm{Ab}}$ & $4.62 \pm 0.02^{\mathrm{Bc}}$ & $4.45 \pm 0.09^{\mathrm{Bd}}$ \\
\hline $\mathrm{T} 2$ & $5.33 \pm 0.03^{\mathrm{Aa}}$ & $5.23 \pm 0.02^{\mathrm{Bb}}$ & $4.95 \pm 0.06^{\mathrm{Bc}}$ & $4.68 \pm 0.02^{\mathrm{Bd}}$ & $4.31 \pm 0.07^{\mathrm{Ce}}$ \\
\hline $\mathrm{T} 3$ & $5.23 \pm 0.03^{\mathrm{Bb}}$ & $5.38 \pm 0.01^{\mathrm{Aa}}$ & $5.14 \pm 0.05^{\mathrm{Ab}}$ & $4.64 \pm 0.07^{\mathrm{Bc}}$ & $4.48 \pm 0.09^{\mathrm{Bd}}$ \\
\hline $\mathrm{T} 4$ & $4.97 \pm 0.03^{\mathrm{Cab}}$ & $5.03 \pm 0.06^{\mathrm{Ca}}$ & $4.90 \pm 0.02 b^{\mathrm{Bb}}$ & $4.94 \pm 0.08^{\mathrm{Aab}}$ & $4.94 \pm 0.02^{\text {Aab }}$ \\
\hline
\end{tabular}

1) Treatments are the same as described in Table 1.

A-C : Means with different superscripts in the same column significantly differ at $\mathrm{p}<0.05$.

a-e : Means with different superscripts in the same row significantly differ at $\mathrm{p}<0.05$.

로 사료된다. 저장기간에 따른 $\mathrm{pH}$ 감소의 원인 에 대해 Paneras와 Bloukas(1994)는 lactobacilli의 작용과 $\mathrm{CO}_{2}$ 가스의 발생으로 인한 것이라고 보고하였다. Choi와 Lee(2002)는 고추장과 된장 양념육을 저장하였을 때 저장기간에 따라 $\mathrm{pH}$ 는 다소 증가하는 경향을 나타내다가 $5{ }^{\circ} \mathrm{C}$ 에서 저장하였을 때는 저장 8 일 이후 $\mathrm{pH}$ 가 감소하 였으며, $10^{\circ} \mathrm{C}$ 에 저장하였을 때는 저장 4 일 이 후에 $\mathrm{pH}$ 가 감소하였는데, 이는 유산균에 의해 생성된 산의 축적에 의한 것이라고 하였다. 일 반적으로 육은 저장기간 동안 단백질 등이 분 해되면서 발생되는 염기성기들과 또한 저장 중 에 산패정도가 높아질수록 식육의 $\mathrm{pH}$ 는 높아 지는 경향을 보인다고 보고하였으며(Holly 등, 1994), 또한 박 등(1997)은 저장 중의 $\mathrm{pH}$ 의 증 가는 온도가 높을수록 지방의 산패가 심하여 과산화물의 축적량이 많고 단백질분해에 의한
암모니아의 생성량이 크기 때문이라고 하였다. 본 연구에서는 전통양념을 이용하여 발효하기 때문에 전체적으로 $\mathrm{pH}$ 가 감소하는 경향을 보 였다. 양파 소스를 이용한 $\mathrm{T} 4$ 처리구는 전 저 장기간 동안 $\mathrm{pH}$ 의 큰 변화가 나타나지 않았다.

\section{2. 염도 및 당도의 변화}

전통양념을 이용한 숙성 돼지고기의 $10^{\circ} \mathrm{C}$ 숙 성 중 양념육의 염도 및 당도의 변화는 Table 3 과 Table 4 에 나타내었다. $10^{\circ} \mathrm{C}$ 에서 숙성시킨 육의 염도는 모든 처리구가 저장 1 일에 비해 저장 4일에 높게 나타났으며 그 이후에는 큰 차이를 나타내지 않았다. 이와 같은 결과는 양 념에 포함되어 있던 3.0 으로 조절했던 염분이 삼투압의 차이로 인해 근육내로 침투하였기 때 문이며, $10^{\circ} \mathrm{C}$ 숙성 시 4 일 정도이면 염분 이동

Table 3. Changes of salinity $(\%)$ of seasoned pork during aging at $10 \pm 1^{\circ} \mathrm{C}$

\begin{tabular}{cccccc}
\hline Treatment $^{1)}$ & \multicolumn{5}{c}{ Storage(days) } \\
\cline { 2 - 6 } & 1 & 4 & 7 & 10 & 13 \\
\hline \hline $\mathrm{T} 1$ & $1.00 \pm 0.03^{\mathrm{Cc}}$ & $1.30 \pm 0.05^{\mathrm{Cb}}$ & $1.34 \pm 0.02^{\mathrm{BCab}}$ & $1.37 \pm 0.03^{\mathrm{ab}}$ & $1.44 \pm 0.14^{\mathrm{ABa}}$ \\
$\mathrm{T} 2$ & $1.20 \pm 0.06^{\mathrm{B}}$ & $1.36 \pm 0.01^{\mathrm{C}}$ & $1.27 \pm 0.16^{\mathrm{C}}$ & $1.32 \pm 0.10$ & $1.28 \pm 0.08^{\mathrm{B}}$ \\
$\mathrm{T} 3$ & $1.00 \pm 0.08^{\mathrm{Cb}}$ & $1.45 \pm 0.01^{\mathrm{Ba}}$ & $1.48 \pm 0.02^{\mathrm{ABa}}$ & $1.49 \pm 0.35^{\mathrm{a}}$ & $1.56 \pm 0.19^{\mathrm{Aa}}$ \\
$\mathrm{T} 4$ & $1.32 \pm 0.04^{\mathrm{A}}$ & $1.55 \pm 0.06^{\mathrm{A}}$ & $1.59 \pm 0.03^{\mathrm{A}}$ & $1.64 \pm 0.13$ & $1.58 \pm 0.01^{\mathrm{A}}$ \\
\hline
\end{tabular}

1) Treatments are the same as described in Table 1.

A-C : Means with different superscripts in the same column significantly differ at $\mathrm{p}<0.05$.

${ }^{\mathrm{a}-\mathrm{c}}$ : Means with different superscripts in the same row significantly differ at $\mathrm{p}<0.05$. 
Table 4. Changes of saccharinity(\%) of seasoned pork during aging at $10 \pm 1^{\circ} \mathrm{C}$

\begin{tabular}{cccccc}
\hline Treatment $^{1)}$ & \multicolumn{5}{c}{ Storage (days) } \\
\cline { 2 - 6 } & 1 & 4 & 7 & 10 & 13 \\
\hline \hline $\mathrm{T} 1$ & $11.63 \pm 0.40^{\mathrm{Bb}}$ & $14.68 \pm 0.26^{\mathrm{a}}$ & $12.99 \pm 0.71^{\mathrm{b}}$ & $12.43 \pm 1.23^{\mathrm{ABb}}$ & $15.12 \pm 0.76^{\mathrm{Aa}}$ \\
$\mathrm{T} 2$ & $11.67 \pm 0.42^{\mathrm{Bbc}}$ & $15.20 \pm 0.63^{\mathrm{a}}$ & $13.07 \pm 1.93^{\mathrm{b}}$ & $10.72 \pm 0.95^{\mathrm{Bc}}$ & $10.04 \pm 0.34^{\mathrm{Bc}}$ \\
$\mathrm{T} 3$ & $11.47 \pm 0.64^{\mathrm{Bc}}$ & $14.87 \pm 0.78^{\mathrm{abc}}$ & $13.58 \pm 1.07^{\mathrm{bc}}$ & $16.11 \pm 3.01^{\mathrm{Aab}}$ & $17.65 \pm 2.55^{\mathrm{Aa}}$ \\
$\mathrm{T} 4$ & $13.91 \pm 1.20^{\mathrm{Ab}}$ & $14.71 \pm 0.16^{\mathrm{ab}}$ & $14.27 \pm 0.64^{\mathrm{b}}$ & $12.83 \pm 1.76^{\mathrm{ABb}}$ & $16.61 \pm 0.75^{\mathrm{Aa}}$ \\
\hline
\end{tabular}

1) Treatments are the same as described in Table 1.

A-B : Means with different superscripts in the same column significantly differ at $\mathrm{p}<0.05$.

${ }^{\mathrm{a}-\mathrm{c}}$ : Means with different superscripts in the same row significantly differ at $\mathrm{p}<0.05$.

이 최대에 가깝게 되는 것으로 나타났다. 처리 구 간의 비교에서는 $\mathrm{T} 4$ 처리구가 전 저장기간 동안 다른 처리구에 비하여 유의적으로 높은 염도를 보였다 $(\mathrm{P}<0.05)$. 이는 일반적으로 양파 소스의 경우 수분이 스며 나와 염 농도가 낮아 짐으로써 낮은 삼투압으로 인해 육의 염도가 낮을 것으로 예상되는데 이에 대한 추가 연구 가 필요할 것으로 사료된다.

$10^{\circ} \mathrm{C}$ 에서 숙성시킨 육의 당도는 모든 처리구 가 저장초기에 비해 저장 말기에 높은 경향을 나타냈으며, 저장 1 일에 비해 저장 4 일에는 유 의적으로 높게 나타났으며, 그 이후에는 큰 차 이를 나타내지 않았다. 저장 1 일에 비해 저장 4 일에 당도가 높은 것은 염도의 결과와 같이 양념에 포함되어 있던 30으로 조절했던 당분이 삼투압의 차이로 인해 근육내로 침투하였기 때 문이며, $10^{\circ} \mathrm{C}$ 숙성시 4 일 정도이면 당분 이동
이 거의 최대에 가깝게 되는 것으로 나타났다. 처리구간의 비교에서는 전 저장기간 동안 처리 구간에 뚜렷한 경향이 없는 것으로 나타났다.

\section{3. 지방산화의 변화}

전통양념을 이용한 숙성 돼지고기의 $10^{\circ} \mathrm{C}$ 숙 성 중 양념육의 지방산화 변화는 Table 5에 나 타내었다. 지방의 산화는 육색소의 산화를 야 기하여 육색을 저하시키고, 이취를 발생시키며 식육의 품질을 저하시킨다. Malonaldehyde는 지 질의 자동산화 연쇄반응 생성물로서 malonaldehyde 함량의 측정은 지질의 산패 정도를 판 정하는데 밀접하게 관계한다. 처리구 간의 비 교에서 저장 7 일까지는 $\mathrm{T} 2$ 와 $\mathrm{T} 3$ 처리구가 $\mathrm{T} 1$ 과 $\mathrm{T} 4$ 처리구에 비하여 유의적으로 낮은 지방 산화를 보였지만 $(\mathrm{P}<0.05), 7$ 일 이후에는 $\mathrm{T} 1$ 과

Table 5. Changes of TBARS (mg malonaldehyde/kg) of seasoned pork during aging at $10 \pm 1^{\circ} \mathrm{C}$

\begin{tabular}{cccccc}
\hline Treatment $^{1)}$ & \multicolumn{4}{c}{ Storage(days) } \\
\cline { 2 - 5 } & 1 & 4 & 7 & 10 & 13 \\
\hline \hline $\mathrm{T} 1$ & $0.13 \pm 0.03^{\mathrm{Ac}}$ & $0.30 \pm 0.09^{\mathrm{Aab}}$ & $0.39 \pm 0.03^{\mathrm{Ba}}$ & $0.26 \pm 0.04^{\mathrm{Bb}}$ & $0.37 \pm 0.10^{\mathrm{BCab}}$ \\
$\mathrm{T} 2$ & $0.08 \pm 0.04^{\mathrm{ABd}}$ & $0.18 \pm 0.01^{\mathrm{Bbc}}$ & $0.16 \pm 0.04^{\mathrm{Cc}}$ & $0.21 \pm 0.01^{\mathrm{Bb}}$ & $0.34 \pm 0.01^{\mathrm{Ca}}$ \\
$\mathrm{T} 3$ & $0.05 \pm 0.01^{\mathrm{Bc}}$ & $0.19 \pm 0.05^{\mathrm{Bb}}$ & $0.14 \pm 0.04^{\mathrm{Cbc}}$ & $0.35 \pm 0.15^{\mathrm{ABa}}$ & $0.48 \pm 0.05^{\mathrm{Ba}}$ \\
$\mathrm{T} 4$ & $0.12 \pm 0.04^{\mathrm{Ac}}$ & $0.26 \pm 0.03^{\mathrm{ABc}}$ & $0.49 \pm 0.02^{\mathrm{Ab}}$ & $0.56 \pm 0.18^{\mathrm{Aab}}$ & $0.70 \pm 0.05^{\mathrm{Aa}}$ \\
\hline
\end{tabular}

1) Treatments are the same as described in Table 1.

A-C : Means with different superscripts in the same column significantly differ at $\mathrm{p}<0.05$.

${ }^{\mathrm{a}-\mathrm{c}}$ : Means with different superscripts in the same row significantly differ at $\mathrm{p}<0.05$. 
$\mathrm{T} 2$ 처리구가 $\mathrm{T} 3$ 와 $\mathrm{T} 4$ 처리구에 비하여 유의적 으로 낮은 지방산화를 보였다 $(\mathrm{P}<0.05)$. 저장기 간에 따라 처리구 간에 지방산화 정도가 다른 것은 양념에 사용된 소스의 종류와 각각의 발 효 특성이 다르기 때문에 산화 정도가 다른 것 으로 사료된다. 전체적으로는 양파 소스를 이 용한 T4 처리구가 다른 처리구에 비하여 유의 적으로 높은 지방산화를 보였다. 저장기간에 따른 변화에서는 모든 처리구가 저장기간이 경 과함에 따라 유의적으로 증가하였다 $(\mathrm{P}<0.05)$. 이와 같은 결과는 1 차 산화생성물질인 hydroperoxide가 2차 산화생성물질로 계속 산화 분해 되어 유기산, 알데하이드, 케톤, 알코올, 카아보 닐기 및 중합체 등이 계속적으로 생성되기 때 문이라 판단된다. 저장기간이 경과함에 따라 지방산화는 직선적으로 상승한다고 보고하였는 데(이 등, 1999 ; 김 등, $2002 \mathrm{~b}$; 이 등, 2003), 본 연구과 일치하는 경향이었다. 식육의 지방산패 도가 높아지는 것은 지방분해 효소 및 미생물 대사 등에 의해 지방이 분해됨으로써 형성되는 분해 물질에 의한 것이라고 보고하였다(Brewer 등, 1992).

\section{4. 휘발성 염기태질소의 변화}

전통양념을 이용한 숙성 돼지고기의 $10^{\circ} \mathrm{C}$ 숙 성 중 양념육의 휘발성 염기태 질소 함량의 변 화는 Table 6에 나타내었다. 처리구 간의 비교 에서는 저장 4일까지 $\mathrm{T} 1$ 처리구가 다른 처리구 에 비하여 유의적으로 높은 휘발성 염기태 질 소 함량을 보였으며 $(\mathrm{P}<0.05), 4$ 일 이후에는 처
리구 간에 뚜렷한 경향이 없었다. 일반적으로 휘발성 염기태 질소화합물은 육류에 많이 오염 되어 있는 pseudomonas spp. 등과 같은 gram negative bacteria에 의해 요소와 아미노산이 분 해됨으로써 형성된다고 하였다(Lefebvre 등, 1994). 저장기간의 경과에 따른 변화에서는 모 든 처리구가 저장기간이 경과함에 따라 유의적 으로 증가하였다. Choi와 Lee(2002)는 양념육을 $10^{\circ} \mathrm{C}$ 에서 저장하였을 때 관능적으로나 미생물 학적으로 부패가 인정된 저장 8 일의 $\mathrm{VBN}$ 값이 $35 \mathrm{mg} \%$ 이하를 나타낸 반면 본 실험에서는 저 장 1 일의 $\mathrm{VBN}$ 값이 $26.68 \sim 49.90 \mathrm{mg} \%$ 를 나타내 었으며, 저장 말에는 최고 $85.52 \mathrm{mg} \%$ 로 상당히 높았지만 미생물학적 관능적 실험결과 부패하 지 않은 것으로 나타났다. 高坂(1975)은 생육의 $\mathrm{VBN}$ 값이 $30 \mathrm{mg} \%$ 이상이 되면 부패한 수준으 로 판정하였으나 육제품은 그 이상이 되어도 부패하지 않은 경우가 있다고 하였다. 본 연구 에서는 $26 \sim 85 \mathrm{mg} \%$ 범위로 매우 높았는데 이는 육 자체에서 기인되는 것보다 소스 제조 시 이 용되었던 각종 양념류 등의 발효에 기인하는 것으로 판단된다. 진 등(2005a)의 보고에 의하 면 된장, 마늘 및 고추장 소스에 10 일간 침지 한 후 저장기간에 따른 $\mathrm{VBN}$ 변화에서 $40 \sim 70$ $\mathrm{mg} \%$ 의 범위를 보였는데, 본 연구의 결과와 일 치하는 경향이었다.

\section{5. 보수력 및 전단력의 변화}

전통양념을 이용한 숙성 돼지고기의 $10^{\circ} \mathrm{C}$ 숙 성 중 양념육의 보수력 및 전단가의 변화를

Table 6. Changes of $\mathrm{VBN}(\mathrm{mg} \%)$ of seasoned pork during aging at $10 \pm 1^{\circ} \mathrm{C}$

\begin{tabular}{cccccc}
\hline \multirow{2}{*}{ Treatment $^{1)}$} & \multicolumn{5}{c}{ Storage(days) } \\
\cline { 2 - 6 } & 1 & 4 & 7 & 10 & 13 \\
\hline \hline $\mathrm{T} 1$ & $49.90 \pm 11.83^{\mathrm{Ab}}$ & $66.60 \pm 6.16^{\mathrm{Aa}}$ & $35.01 \pm 1.69^{\mathrm{Bb}}$ & $75.21 \pm 5.58^{\mathrm{Aa}}$ & $76.35 \pm 2.95^{\mathrm{Ba}}$ \\
$\mathrm{T} 2$ & $28.55 \pm 4.35^{\mathrm{Bb}}$ & $29.32 \pm 5.58^{\mathrm{Bb}}$ & $33.78 \pm 5.35^{\mathrm{Bab}}$ & $39.09 \pm 2.17^{\mathrm{Ba}}$ & $40.20 \pm 1.15^{\mathrm{Ca}}$ \\
$\mathrm{T} 3$ & $26.68 \pm 6.04^{\mathrm{Bc}}$ & $37.06 \pm 1.87^{\mathrm{Bd}}$ & $46.07 \pm 0.34^{\mathrm{Bc}}$ & $75.89 \pm 2.75^{\mathrm{Ab}}$ & $85.52 \pm 4.29^{\mathrm{Aa}}$ \\
$\mathrm{T} 4$ & $29.44 \pm 4.00^{\mathrm{bB}}$ & $33.77 \pm 4.46^{\mathrm{Bb}}$ & $63.57 \pm 16.63^{\mathrm{Aa}}$ & $71.79 \pm 2.64^{\mathrm{Aa}}$ & $32.31 \pm 3.69^{\mathrm{Db}}$ \\
\hline
\end{tabular}

1) Treatments are the same as described in Table 1.

A-D : Means with different superscripts in the same column significantly differ at $p<0.05$.

a-d : Means with different superscripts in the same row significantly differ at $\mathrm{p}<0.05$. 
Table 7과 8에 각각 나타내었다. 저장기간의 경 과에 따른 보수력의 변화에서 모든 처리구가 저장 7 일까지는 보수력이 증가하다가 그 이후 감소하는 경향을 나타내었으며 $\mathrm{T} 1$ 처리구와 $\mathrm{T} 4$ 처리구는 저장 13 일 다시 보수력이 상승하 였다. 처리구에 따른 변화를 보면 $\mathrm{T} 1$ 처리구가 다른 처리구에 비하여 저장 1 일에 유의적으로 낮은 보수력을 나타내었으나 $(\mathrm{P}<0.05)$ 그 이후에 는 큰 차이를 나타내지 않았으며, 저장 13 일에 는 $\mathrm{T} 4$ 처리구가 다른 처리구에 비해 유의적으 로 높은 보수력을 나타내었다 $(\mathrm{P}<0.05)$. 육이 물 리적인 처리를 받았을 때 수분을 잃지 않고 함 유할 수 있는 성질을 보수력이라고 말할 수 있 는 데, 육의 이화학적 성질 중의 하나로 육의 기능적 성질(결착력, 유화력)과 최종제품의 생 산량에 지대한 영향을 미치는 요인으로서 작용 한다. 전체적으로 전 저장기간 동안 보수력은 $62.52 \sim 82.72 \%$ 의 범위를 보였다.
육류의 화학적 조성도 육의 구조에 영향을 미치며, 물리적 성질을 결정하는데 관여한다. 이러한 복잡한 요인에 의해 육류의 조직감이 결정되고, 관능적 특성도 아울러 결정된다. 육 의 조직감 측정은 육질을 평가하는데 가장 중 요한 방법 중의 하나이며, 육류의 조직은 소비 자들이 육의 맛을 평가하는데 중요한 기준이 된다. 전단력은 저장기간이 경과함에 따라 모 든 처리구가 감소하는 경향을 나타내었으며, 특히 저장 1 일에 비하여 저장 4 일에는 감소폭 이 크게 나타났다. 처리구 간의 비교에서는 저 장 7일까지 $\mathrm{T} 2$ 처리구가 다른 처리구에 비하여 유의적으로 높았다 $(\mathrm{P}<0.05)$. 이는 보수력이 높 으면 전단력은 일반적으로 낮아지는 것과 상반 된 결과를 보였는데 추가적인 연구가 필요하다 고 사료된다. 한편 7일 이후에는 $\mathrm{T} 4$ 처리구가 다른 처리구에 비하여 유의적으로 높은 전단력 을 보였다 $(\mathrm{P}<0.05)$.

Table 7. Changes of water holding capacity(\%) of seasoned pork during aging at $10 \pm 1^{\circ} \mathrm{C}$

\begin{tabular}{cccccc}
\hline Treatment $^{1}{ }^{1}$ & \multicolumn{5}{c}{ Storage(days) } \\
\cline { 2 - 6 } & 1 & 4 & 7 & 10 & 13 \\
\hline \hline $\mathrm{T} 1$ & $62.52 \pm 1.39^{\mathrm{Bc}}$ & $79.95 \pm 2.91^{\mathrm{Aa}}$ & $82.72 \pm 3.69^{\mathrm{Aa}}$ & $70.91 \pm 2.72^{\mathrm{ABb}}$ & $73.48 \pm 2.32^{\mathrm{Bb}}$ \\
$\mathrm{T} 2$ & $74.98 \pm 2.76^{\mathrm{Ab}}$ & $75.04 \pm 3.53^{\mathrm{Bb}}$ & $82.14 \pm 2.61^{\mathrm{ABa}}$ & $69.98 \pm 3.54^{\mathrm{Bc}}$ & $68.58 \pm 2.60^{\mathrm{Bc}}$ \\
$\mathrm{T} 3$ & $74.51 \pm 1.79^{\mathrm{Aa}}$ & $76.55 \pm 1.76^{\mathrm{ABa}}$ & $77.59 \pm 3.77^{\mathrm{Ba}}$ & $74.21 \pm 3.08^{\mathrm{ABa}}$ & $68.54 \pm 4.06^{\mathrm{Bb}}$ \\
$\mathrm{T} 4$ & $74.77 \pm 0.16^{\mathrm{A}}$ & $78.50 \pm 4.41^{\mathrm{AB}}$ & $78.81 \pm 3.92^{\mathrm{AB}}$ & $76.70 \pm 7.30^{\mathrm{A}}$ & $81.16 \pm 7.87^{\mathrm{A}}$ \\
\hline
\end{tabular}

1) Treatments are the same as described in Table 1.

A-B : Means with different superscripts in the same column significantly differ at $\mathrm{p}<0.05$.

a-c : Means with different superscripts in the same row significantly differ at $\mathrm{p}<0.05$.

Table 8. Changes of shear force $\left(\mathrm{g} / \mathrm{cm}^{2}\right)$ of seasoned pork during aging at $10 \pm 1^{\circ} \mathrm{C}$

\begin{tabular}{|c|c|c|c|c|c|}
\hline \multirow{2}{*}{ Treatment $^{1)}$} & \multicolumn{5}{|c|}{ Storage(days) } \\
\hline & 1 & 4 & 7 & 10 & 13 \\
\hline $\mathrm{T} 1$ & $7,253 \pm 2,216^{\mathrm{Ba}}$ & $3,745 \pm 893^{\mathrm{Bb}}$ & $3,671 \pm 2,019^{\mathrm{Bb}}$ & $3,300 \pm 891^{\mathrm{Abc}}$ & $1,625 \pm 421^{\mathrm{Bc}}$ \\
\hline $\mathrm{T} 2$ & $15,138 \pm 9,676^{\mathrm{Aa}}$ & $12,090 \pm 8,181^{\mathrm{Aa}}$ & $11,387 \pm 7,814^{\mathrm{Aa}}$ & $1,734 \pm 682^{\mathrm{Bb}}$ & $1,874 \pm 521^{\mathrm{Bb}}$ \\
\hline $\mathrm{T} 3$ & $9,026 \pm 2,792^{\mathrm{ABa}}$ & $2,406 \pm 950^{\mathrm{Bb}}$ & $2,406 \pm 950^{\mathrm{Bb}}$ & $1,746 \pm 305^{\mathrm{Bb}}$ & $1,764 \pm 147^{\mathrm{Bb}}$ \\
\hline $\mathrm{T} 4$ & $4,695 \pm 2,530^{\mathrm{Ba}}$ & $1,193 \pm 648^{\mathrm{Bb}}$ & $1,193 \pm 648^{\mathrm{Bb}}$ & $3,206 \pm 745^{\mathrm{Aa}}$ & $3,062 \pm 441^{\mathrm{Aa}}$ \\
\hline
\end{tabular}

\footnotetext{
1) Treatments are the same as described in Table 1.

A-B : Means with different superscripts in the same column significantly differ at $p<0.05$.

${ }^{\mathrm{a}-\mathrm{c}}$ : Means with different superscripts in the same row significantly differ at $\mathrm{p}<0.05$.
} 


\section{6. 표면 및 심부 육색의 변화}

전통양념을 이용한 숙성 돼지고기의 $10^{\circ} \mathrm{C}$ 숙 성 중 양념육의 표면 육색 및 심부 육색변화를 Table 9와 10 에 각각 나타내었다. 소비자들의 식육 구입시 주요 관점은 외관 형질 즉, 육색 을 기초로 하여 구매한다(Zhu와 Brewer, 1998). 또한 육색은 돈육의 품질을 좌우하게 되고, 냉 장돈육에서 정상적인 육색은 돈육산업에 있어 서 대단히 중요하다(Warner 등, 1993). 육색은 주로 명도와 적색도를 주로 관찰하며 적색도가 높을수록 좋은 품질로 평가받고 있다. 표면 육 색 중 $\mathrm{L}^{*}$ 값은 $\mathrm{T} 1$ 처리구를 제외한 모든 처리 구가 저장기간이 경과함에 따라 증가하는 경향 을 나타내었으며, 처리구 간의 비교에서는 저 장 1 일을 제외한 전 저장기간 동안 $\mathrm{T} 1$ 처리구 가 다른 처리구에 비하여 유의적으로 낮은 명 도 값을 보였다 $(\mathrm{P}<0.05)$. a*값은 김치 소스로 양념 숙성한 $\mathrm{T} 2$ 처리구가 다른 처리구에 비하 여 유의적으로 높은 적색도를 보였는데, 이는
김치 소스에 포함된 고춧가루 색소가 육에 침 착되어 적색도가 높은 것으로 사료된다. 저장 기간의 경과에 따른 변화에서는 모든 처리구가 뚜렷한 경향이 없는 것으로 나타났다. $\mathrm{b}$ *값도 김치 소스로 양념 숙성한 $\mathrm{T} 2$ 처리구가 다른 처 리구에 비하여 유의적으로 높은 황색도를 보였 는데, 이는 김치 소스에 포함된 각종 성분들이 황색도를 변화 시키는 것으로 사료된다. T2 처 리구를 제외한 모든 처리구가 저장기간이 경과 함에 따라 황색도가 증가하는 것으로 나타났 다.

심부 육색 중 $\mathrm{L}^{*}$ 값은 모든 처리구가 저장 1 일에 유의적으로 가장 높고 저장 7일까지 감소 한 후 다시 증가되었다가 다시 감소하는 패턴 을 보였다. 처리구 간의 비교에서는 김치 소스 로 양념 숙성한 $\mathrm{T} 2$ 처리구가 전 저장기간 동안 다른 처리구에 비하여 낮은 $\mathrm{L}^{*}$ 값을 보였다. $\mathrm{a}^{*}$ 값은 $\mathrm{T} 2$ 처리구가 다른 처리구에 비하여 유의 적으로 높은 값을 보였다 $(\mathrm{P}<0.05)$. 이는 표면 육색의 경과와 같이 김치소스에 포함되어 있는

Table 9. Changes of surface meat color(Hunter $\left.L^{*}, a^{*}, b^{*}\right)$ of seasoned pork during aging at $10 \pm 1^{\circ} \mathrm{C}$

\begin{tabular}{|c|c|c|c|c|c|c|}
\hline & \multirow{2}{*}{ Treatment $^{1)}$} & \multicolumn{5}{|c|}{ Storage(days) } \\
\hline & & 1 & 4 & 7 & 10 & 13 \\
\hline \multirow{4}{*}{$\mathrm{L} *$} & $\mathrm{~T} 1$ & $32.81 \pm 2.50^{\mathrm{Bb}}$ & $35.79 \pm 1.68^{\mathrm{Bab}}$ & $35.79 \pm 1.68^{\mathrm{Bab}}$ & $37.06 \pm 2.48^{\mathrm{Ba}}$ & $38.03 \pm 2.32^{\mathrm{Ca}}$ \\
\hline & $\mathrm{T} 2$ & $35.65 \pm 2.17^{\mathrm{Bc}}$ & $43.61 \pm 1.53^{\mathrm{Ab}}$ & $43.61 \pm 1.53^{\mathrm{Ab}}$ & $48.48 \pm 1.57^{\mathrm{Aa}}$ & $49.28 \pm 1.88^{\mathrm{Aa}}$ \\
\hline & $\mathrm{T} 3$ & $31.91 \pm 2.16^{\mathrm{Bd}}$ & $41.55 \pm 2.18^{\mathrm{Ac}}$ & $41.55 \pm 2.18^{\mathrm{Ac}}$ & $46.67 \pm 2.44^{\mathrm{Ab}}$ & $50.29 \pm 2.07^{\mathrm{Aa}}$ \\
\hline & $\mathrm{T} 4$ & $43.03 \pm 5.13^{\mathrm{A}}$ & $43.26 \pm 2.82^{\mathrm{A}}$ & $43.26 \pm 2.82^{\mathrm{A}}$ & $45.13 \pm 2.98^{\mathrm{A}}$ & $43.95 \pm 1.61^{\mathrm{B}}$ \\
\hline \multirow{4}{*}{$a *$} & $\mathrm{~T} 1$ & $3.04 \pm 0.44^{\mathrm{BCc}}$ & $2.78 \pm 0.65^{\mathrm{Bc}}$ & $2.78 \pm 0.65^{\mathrm{Bc}}$ & $4.42 \pm 0.91^{\mathrm{Bb}}$ & $6.04 \pm 1.65^{\mathrm{Aa}}$ \\
\hline & $\mathrm{T} 2$ & $7.21 \pm 0.43^{\mathrm{Aa}}$ & $5.79 \pm 0.85^{\mathrm{Ab}}$ & $5.79 \pm 0.85^{\mathrm{Ab}}$ & $7.28 \pm 1.29^{\mathrm{Aa}}$ & $7.48 \pm 1.31^{\mathrm{Aa}}$ \\
\hline & $\mathrm{T} 3$ & $3.42 \pm 0.53^{\mathrm{Bb}}$ & $2.28 \pm 0.23^{\mathrm{Bc}}$ & $2.28 \pm 0.23^{\mathrm{Bc}}$ & $5.35 \pm 1.62^{\mathrm{Ba}}$ & $3.53 \pm 0.28^{\mathrm{Bb}}$ \\
\hline & $\mathrm{T} 4$ & $1.98 \pm 1.87^{\mathrm{Ca}}$ & $0.50 \pm 0.38^{\mathrm{Cb}}$ & $0.50 \pm 0.38^{\mathrm{Cb}}$ & $-0.11 \pm 0.65^{\mathrm{Cb}}$ & $1.01 \pm 0.54^{\mathrm{Cab}}$ \\
\hline \multirow{4}{*}{ b* } & $\mathrm{T} 1$ & $6.34 \pm 1.17^{\mathrm{Bc}}$ & $8.51 \pm 0.56^{\mathrm{Ab}}$ & $8.51 \pm 0.56^{\mathrm{Ab}}$ & $7.91 \pm 1.62^{\mathrm{Cb}}$ & $10.49 \pm 1.53^{\mathrm{Ba}}$ \\
\hline & $\mathrm{T} 2$ & $13.01 \pm 0.79^{\mathrm{Aa}}$ & $9.46 \pm 1.22^{\mathrm{Ab}}$ & $9.46 \pm 1.22^{\mathrm{Ab}}$ & $13.79 \pm 1.20^{\mathrm{Aa}}$ & $13.39 \pm 1.44^{\mathrm{Aa}}$ \\
\hline & $\mathrm{T} 3$ & $3.18 \pm 0.99^{\mathrm{Cc}}$ & $6.73 \pm 0.46^{\mathrm{Bb}}$ & $6.73 \pm 0.46^{\mathrm{Bb}}$ & $10.26 \pm 0.69^{\mathrm{Ba}}$ & $9.88 \pm 0.55^{\mathrm{Ba}}$ \\
\hline & $\mathrm{T} 4$ & $3.18 \pm 1.28^{\mathrm{Cb}}$ & $4.19 \pm 1.93^{\mathrm{Cab}}$ & $4.19 \pm 1.93^{\mathrm{Cab}}$ & $5.53 \pm 0.85^{\mathrm{Da}}$ & $5.84 \pm 1.02^{\mathrm{Ca}}$ \\
\hline
\end{tabular}

\footnotetext{
1) Treatments are the same as described in Table 1.

A-C : Means with different superscripts in the same column significantly differ at $\mathrm{p}<0.05$.

a-d : Means with different superscripts in the same row significantly differ at $\mathrm{p}<0.05$.
} 
Table 10. Changes of inner meat color(Hunter $\left.L^{*}, a^{*}, b^{*}\right)$ of seasoned pork during aging at $10 \pm 1^{\circ} \mathrm{C}$

\begin{tabular}{|c|c|c|c|c|c|c|}
\hline & \multirow{2}{*}{ Treatment $^{1)}$} & \multicolumn{5}{|c|}{ Storage(days) } \\
\hline & & 1 & 4 & 7 & 10 & 13 \\
\hline \multirow{4}{*}{$\mathrm{L}^{*}$} & $\mathrm{~T} 1$ & $47.17 \pm 2.84^{\mathrm{Aa}}$ & $38.44 \pm 1.10^{\mathrm{Ac}}$ & $38.44 \pm 1.10^{\mathrm{Ac}}$ & $43.28 \pm 1.84^{\mathrm{Ab}}$ & $39.05 \pm 1.19^{\mathrm{Ac}}$ \\
\hline & $\mathrm{T} 2$ & $38.17 \pm 2.46^{\mathrm{Ca}}$ & $37.01 \pm 1.64^{\mathrm{ABab}}$ & $37.01 \pm 1.64^{\mathrm{ABab}}$ & $35.06 \pm 0.60^{\mathrm{Bbc}}$ & $34.26 \pm 0.68^{\mathrm{Bc}}$ \\
\hline & $\mathrm{T} 3$ & $43.46 \pm 1.41^{\mathrm{Ba}}$ & $39.49 \pm 0.56^{\mathrm{Ab}}$ & $39.49 \pm 0.56^{\mathrm{Ab}}$ & $42.79 \pm 1.95^{\mathrm{Aa}}$ & $37.09 \pm 1.02^{\mathrm{Ab}}$ \\
\hline & $\mathrm{T} 4$ & $47.10 \pm 0.47^{\mathrm{Aa}}$ & $34.69 \pm 3.46^{\mathrm{Bb}}$ & $34.69 \pm 3.46^{\mathrm{Bb}}$ & $35.30 \pm 2.54^{\mathrm{Bb}}$ & $38.56 \pm 3.47^{\mathrm{Ab}}$ \\
\hline \multirow{4}{*}{$a^{*}$} & $\mathrm{~T} 1$ & $3.10 \pm 0.90^{\mathrm{Cd}}$ & $4.01 \pm 0.39^{\mathrm{Bc}}$ & $4.01 \pm 0.39^{\mathrm{Bc}}$ & $4.99 \pm 0.58^{\mathrm{Bb}}$ & $6.06 \pm 0.36^{\mathrm{Ba}}$ \\
\hline & $\mathrm{T} 2$ & $5.39 \pm 0.33^{\mathrm{Ab}}$ & $10.85 \pm 2.80^{\mathrm{Aa}}$ & $10.85 \pm 2.80^{\mathrm{Aa}}$ & $6.74 \pm 0.45^{\mathrm{Ab}}$ & $7.14 \pm 0.63^{\mathrm{Ab}}$ \\
\hline & $\mathrm{T} 3$ & $3.98 \pm 0.35^{\mathrm{Bb}}$ & $4.69 \pm 0.73^{\mathrm{Bb}}$ & $4.69 \pm 0.73^{\mathrm{Bb}}$ & $6.26 \pm 0.81^{\mathrm{Aa}}$ & $5.84 \pm 0.35^{\mathrm{Ba}}$ \\
\hline & $\mathrm{T} 4$ & $3.27 \pm 0.45^{\mathrm{BCab}}$ & $4.19 \pm 1.97^{\mathrm{Ba}}$ & $4.19 \pm 1.97^{\mathrm{Ba}}$ & $3.98 \pm 0.54^{\mathrm{Ca}}$ & $1.79 \pm 0.83^{\mathrm{Cb}}$ \\
\hline \multirow{4}{*}{$b^{*}$} & $\mathrm{~T} 1$ & $2.85 \pm 0.97^{\mathrm{Bb}}$ & $2.25 \pm 0.18^{\mathrm{Bb}}$ & $2.25 \pm 0.18^{\mathrm{Bb}}$ & $4.07 \pm 0.54^{\mathrm{Aa}}$ & $4.20 \pm 0.31^{\mathrm{Aa}}$ \\
\hline & $\mathrm{T} 2$ & $4.55 \pm 1.13^{\mathrm{Ab}}$ & $6.97 \pm 2.31^{\mathrm{Aa}}$ & $6.97 \pm 2.31^{\mathrm{Aa}}$ & $4.32 \pm 0.40^{\mathrm{Ab}}$ & $4.17 \pm 0.36^{\mathrm{Ab}}$ \\
\hline & $\mathrm{T} 3$ & $2.69 \pm 0.80^{\mathrm{Bc}}$ & $3.22 \pm 0.58^{\mathrm{Bbc}}$ & $3.22 \pm 0.58^{\mathrm{Bbc}}$ & $5.07 \pm 0.97^{\mathrm{Aa}}$ & $3.74 \pm 0.37^{\mathrm{Ab}}$ \\
\hline & $\mathrm{T} 4$ & $3.40 \pm 0.53^{\mathrm{AB}}$ & $1.91 \pm 1.90^{\mathrm{B}}$ & $1.91 \pm 1.90^{\mathrm{B}}$ & $1.61 \pm 0.80^{\mathrm{B}}$ & $2.36 \pm 1.13^{\mathrm{B}}$ \\
\hline
\end{tabular}

1) Treatments are the same as described in Table 1.

A-C : Means with different superscripts in the same column significantly differ at $\mathrm{p}<0.05$.

a-c : Means with different superscripts in the same row significantly differ at $\mathrm{p}<0.05$.

색소 성분이 육 내부에 침투된 것으로 사료된 다. 저장기간의 경과에 따른 변화에서는 모든 처리구가 뚜렷한 경향이 없었다. $\mathrm{b}$ *값은 $\mathrm{T} 2$ 처 리구가 다른 처리구에 비하여 유의적으로 높은 값을 보였으며 $(\mathrm{P}<0.05)$, 저장기간의 따른 변화 에서는 모든 처리구가 뚜렷한 경향이 없었다.

\section{7. 관능적 특성의 변화}

전통양념을 이용한 숙성 돼지고기의 $10^{\circ} \mathrm{C}$ 숙 성 중 양념육의 관능적 특성 변화는 Table 11 에 나타내었다. 식육의 기호성은 가열육을 입 속에서 씹어 넘기는 과정에 혀의 감각으로 느 껴지는 맛, 후각으로 느껴지는 향 그리고 조직 감 등을 포함하여 판단하게 된다. 이들 중 어 느 것이 기호성에 크게 관여하는 지는 식육의 종류에 따라 다르며, 양념육이나 육제품의 경 우에는 이들 제품에 첨가된 향신료에 의해 크
게 작용을 하게 된다. 향은 전 저장기간 동안 처리구 간에는 유의적인 차이가 없었으며, 저 장기간이 경과할수록 감소하는 경향을 보였다. 풍미는 처리구 간에 뚜렷한 차이가 없는 것으 로 나타났으며, 저장기간의 경과에 따른 변화 에서도 뚜렷한 차이가 없었다. 연도는 처리구 간에 비교에서 전 저장기간 동안 새우젓 소스 로 양념 숙성한 $\mathrm{T} 3$ 처리구가 다른 처리구에 비 하여 낮은 연도를 보였으며, 저장기간의 경과 에 따른 변화에서는 뚜렷한 경향이 없었다. 다 즙성은 전 저장기간 동안 $\mathrm{T} 3$ 처리구가 다른 처 리구에 비하여 낮은 다즙성을 보였으며, 저장 기간의 경과에 따른 변화에서는 모든 처리구가 뚜렷한 경향이 없었다. 전체적인 기호성은 전 저장기간 동안 $\mathrm{T} 3$ 처리구가 낮은 기호성을 보 였으며, 저장기간의 경과에 따른 변화에서는 모든 처리구가 뚜렷한 경향이 없었다. 
Jin et al. ; Quality Characteristics of Seasonings Fermented Pork with Atmosphere Packaging

Table 11. Changes of sensory evaluation of seasoned pork during aging at $10 \pm 1^{\circ} \mathrm{C}$

\begin{tabular}{|c|c|c|c|c|c|c|}
\hline & \multirow{2}{*}{ Treatment $^{1)}$} & \multicolumn{5}{|c|}{ Storage(days) } \\
\hline & & 1 & 4 & 7 & 10 & 13 \\
\hline \multirow{4}{*}{ Aroma } & $\mathrm{T} 1$ & $6.60 \pm 1.34$ & $6.20 \pm 0.45$ & $6.00 \pm 0.71$ & $5.80 \pm 0.84$ & $5.80 \pm 1.30$ \\
\hline & $\mathrm{T} 2$ & $6.40 \pm 1.14^{\mathrm{a}}$ & $6.20 \pm 0.84^{\mathrm{a}}$ & $5.20 \pm 0.84^{\mathrm{ab}}$ & $4.60 \pm 1.34^{\mathrm{b}}$ & $5.20 \pm 1.10^{\mathrm{ab}}$ \\
\hline & $\mathrm{T} 3$ & $5.80 \pm 0.84$ & $5.80 \pm 1.79$ & $5.60 \pm 0.55$ & $4.80 \pm 1.10$ & $5.00 \pm 1.41$ \\
\hline & $\mathrm{T} 4$ & $7.00 \pm 0.71^{\mathrm{a}}$ & $6.20 \pm 0.84^{\mathrm{ab}}$ & $5.80 \pm 0.84^{\mathrm{ab}}$ & $5.00 \pm 2.12^{\mathrm{b}}$ & $5.80 \pm 1.30^{\mathrm{ab}}$ \\
\hline \multirow{4}{*}{ Flavor } & $\mathrm{T} 1$ & $5.80 \pm 0.45^{\mathrm{AB}}$ & $6.60 \pm 0.89$ & $6.60 \pm 0.55$ & $5.60 \pm 0.55^{\mathrm{A}}$ & $5.80 \pm 1.30$ \\
\hline & $\mathrm{T} 2$ & $6.20 \pm 1.79^{\mathrm{ABa}}$ & $6.60 \pm 0.89^{\mathrm{a}}$ & $5.80 \pm 0.84^{\mathrm{a}}$ & $3.80 \pm 1.48^{\mathrm{Bb}}$ & $5.20 \pm 1.30^{\mathrm{ab}}$ \\
\hline & $\mathrm{T} 3$ & $5.20 \pm 1.48^{\mathrm{B}}$ & $5.80 \pm 1.64$ & $5.40 \pm 1.14$ & $4.60 \pm 0.89^{\mathrm{AB}}$ & $4.80 \pm 0.84$ \\
\hline & $\mathrm{T} 4$ & $7.00 \pm 0.71^{\mathrm{Aa}}$ & $6.60 \pm 1.14^{\mathrm{a}}$ & $5.80 \pm 0.84^{\mathrm{ab}}$ & $4.60 \pm 1.67^{\mathrm{ABb}}$ & $4.80 \pm 0.84^{b}$ \\
\hline \multirow{4}{*}{ Tenderness } & $\mathrm{T} 1$ & $5.60 \pm 0.89^{\mathrm{ABab}}$ & $6.00 \pm 0.71^{\mathrm{ABab}}$ & $6.60 \pm 0.55^{\mathrm{Aa}}$ & $5.80 \pm 0.45^{\mathrm{ab}}$ & $5.40 \pm 0.89^{b}$ \\
\hline & $\mathrm{T} 2$ & $6.20 \pm 1.30^{\mathrm{Aab}}$ & $6.40 \pm 0.55^{\mathrm{Aa}}$ & $6.00 \pm 0.71^{\mathrm{ABab}}$ & $4.80 \pm 1.30^{\mathrm{b}}$ & $5.20 \pm 0.84^{\mathrm{ab}}$ \\
\hline & $\mathrm{T} 3$ & $4.60 \pm 1.14^{\mathrm{B}}$ & $5.00 \pm 1.22^{\mathrm{B}}$ & $5.40 \pm 0.89^{\mathrm{B}}$ & $4.60 \pm 2.07$ & $4.80 \pm 0.45$ \\
\hline & $\mathrm{T} 4$ & $6.40 \pm 0.55^{\mathrm{A}}$ & $5.80 \pm 1.10^{\mathrm{AB}}$ & $6.00 \pm 0.71^{\mathrm{AB}}$ & $5.00 \pm 1.22$ & $5.20 \pm 1.10$ \\
\hline \multirow{4}{*}{ Juiciness } & $\mathrm{T} 1$ & $5.60 \pm 1.14^{\mathrm{ABab}}$ & $5.60 \pm 0.89^{\mathrm{ab}}$ & $6.40 \pm 0.55^{\mathrm{Aa}}$ & $5.20 \pm 1.30^{\mathrm{ab}}$ & $4.40 \pm 0.89^{b}$ \\
\hline & $\mathrm{T} 2$ & $6.00 \pm 1.22^{\mathrm{AB}}$ & $5.80 \pm 0.84$ & $5.60 \pm 0.55^{\mathrm{AB}}$ & $4.80 \pm 1.79$ & $5.00 \pm 1.22$ \\
\hline & $\mathrm{T} 3$ & $4.60 \pm 1.14^{\mathrm{B}}$ & $5.00 \pm 1.41$ & $5.40 \pm 0.89^{\mathrm{B}}$ & $4.60 \pm 1.52$ & $4.60 \pm 0.55$ \\
\hline & $\mathrm{T} 4$ & $6.60 \pm 0.55^{\mathrm{Aa}}$ & $5.40 \pm 1.14^{\mathrm{abc}}$ & $6.20 \pm 0.45^{\mathrm{ABab}}$ & $5.00 \pm 1.73^{\mathrm{bc}}$ & $4.40 \pm 0.55^{\mathrm{c}}$ \\
\hline \multirow{4}{*}{ Acceptability } & $\mathrm{T} 1$ & $6.20 \pm 1.30^{\mathrm{AB}}$ & $6.40 \pm 1.14$ & $6.40 \pm 0.55^{\mathrm{A}}$ & $5.60 \pm 0.55$ & $5.80 \pm 1.30$ \\
\hline & $\mathrm{T} 2$ & $6.20 \pm 1.30^{\mathrm{ABa}}$ & $6.60 \pm 0.89^{\mathrm{a}}$ & $5.60 \pm 0.55^{\mathrm{ABa}}$ & $3.80 \pm 1.79^{\mathrm{b}}$ & $5.60 \pm 1.14^{\mathrm{a}}$ \\
\hline & $\mathrm{T} 3$ & $4.80 \pm 1.48^{\mathrm{B}}$ & $5.20 \pm 1.30$ & $5.20 \pm 0.84^{\mathrm{B}}$ & $4.40 \pm 0.89$ & $4.60 \pm 0.55$ \\
\hline & $\mathrm{T} 4$ & $7.20 \pm 0.84^{\mathrm{Aa}}$ & $6.20 \pm 1.48^{\mathrm{ab}}$ & $5.80 \pm 0.84^{\mathrm{ABab}}$ & $5.20 \pm 1.92^{\mathrm{b}}$ & $5.20 \pm 1.10^{\mathrm{b}}$ \\
\hline
\end{tabular}

\section{8. 미생물의 변화}

전통양념을 이용한 숙성 돼지고기의 $10^{\circ} \mathrm{C}$ 숙 성 중 양념육의 미생물 변화는 Table 12 14에 나타내었다. 총균수에서 저장기간의 경과에 따 른 변화를 보면 모든 처리구가 저장 7일까지 급격히 증가하다 7일 이후 감소하는 경향을 나 타내었으며 처리구에 따른 변화를 보면 저장 1 일에는 $\mathrm{T} 2$ 구가 높고 $\mathrm{T} 4$ 구가 낮게 나타났으나 저장 4일부터 $\mathrm{T} 3$ 구가 높게 $\mathrm{T} 4$ 구는 낮게 나타 났으며 전 저장기간 동안 이러한 경향을 나타 내어 처리구 간에 뚜렷한 경향이 없었다. 대장
균은 처리구 간의 비교에서 저장 10 일까지 김 치소스로 양념 숙성한 $\mathrm{T} 2$ 처리구가 다른 처리 구에 비하여 유의적으로 높은 대장균수를 보였 으며 $(\mathrm{P}<0.05)$, 저장 13 일에는 $\mathrm{T} 3>\mathrm{T} 2>\mathrm{T} 4>\mathrm{T} 1$ 의 순으로 대장균수가 많았다. 저장기간의 경과에 따른 변화에서는 모든 처리구가 뚜렷한 경향이 없는 것으로 나타났다. 유산균은 처리구 간의 비교에서 전 저장기간 동안 $\mathrm{T} 2$ 와 $\mathrm{T} 3$ 처리구가 $\mathrm{T} 1$ 과 $\mathrm{T} 4$ 처리구에 비하여 유의적으로 높은 유 산균수를 보였으며 $(\mathrm{P}<0.05)$, 이와 같은 결과는 김치와 새우젓 소스가 간장과 양파 소스에 비 하여 저장 동안 유산균수가 많은 것으로 사료 
Table 12. Changes of total plate counts $\left(\log _{10} \mathrm{CFU} / \mathrm{cm}^{2}\right)$ of seasoned pork during aging at $10 \pm 1^{\circ} \mathrm{C}$

\begin{tabular}{cccccc}
\hline \multirow{2}{*}{ Treatment $^{1)}$} & \multicolumn{5}{c}{ Storage(days) } \\
\cline { 2 - 6 } & 1 & 4 & 7 & 10 & 13 \\
\hline \hline $\mathrm{T} 1$ & $4.28 \pm 0.04^{\mathrm{Ce}}$ & $4.97 \pm 0.03^{\mathrm{Cd}}$ & $7.52 \pm 0.04^{\mathrm{Aa}}$ & $6.22 \pm 0.17^{\mathrm{ABb}}$ & $5.57 \pm 0.04^{\mathrm{Cc}}$ \\
$\mathrm{T} 2$ & $5.16 \pm 0.02^{\mathrm{Ad}}$ & $5.25 \pm 0.05^{\mathrm{Bc}}$ & $7.27 \pm 0.02^{\mathrm{Ca}}$ & $5.65 \pm 0.05^{\mathrm{Cb}}$ & $4.65 \pm 0.05^{\mathrm{De}}$ \\
$\mathrm{T} 3$ & $4.60 \pm 0.08^{\mathrm{Bd}}$ & $6.19 \pm 0.04^{\mathrm{Ac}}$ & $7.38 \pm 0.02^{\mathrm{Ba}}$ & $6.32 \pm 0.01^{\mathrm{Ab}}$ & $6.19 \pm 0.02^{\mathrm{Ac}}$ \\
$\mathrm{T} 4$ & $3.95 \pm 0.01^{\mathrm{Dd}}$ & $3.81 \pm 0.03^{\mathrm{De}}$ & $5.67 \pm 0.03^{\mathrm{Dc}}$ & $6.09 \pm 0.05^{\mathrm{Ba}}$ & $5.83 \pm 0.00^{\mathrm{Bb}}$ \\
\hline
\end{tabular}

1) Treatments are the same as described in Table 1.

A-D : Means with different superscripts in the same column significantly differ at $\mathrm{p}<0.05$.

a-e : Means with different superscripts in the same row significantly differ at $\mathrm{p}<0.05$.

Table 13. Changes of Escherichia coli $\left(\log _{10} \mathrm{CFU} / \mathrm{cm}^{2}\right)$ of seasoned pork during aging at $10 \pm 1^{\circ} \mathrm{C}$

\begin{tabular}{cccccc}
\hline \multirow{2}{*}{ Treatment $^{1)}$} & \multicolumn{5}{c}{ Storage(days) } \\
\cline { 2 - 6 } & 1 & 4 & 7 & 10 & 13 \\
\hline \hline $\mathrm{T} 1$ & $2.33 \pm 0.01^{\mathrm{Cd}}$ & $2.69 \pm 0.09^{\mathrm{Cc}}$ & $3.11 \pm 0.14^{\mathrm{Cb}}$ & $4.23 \pm 0.03^{\mathrm{Ba}}$ & $2.29 \pm 0.01^{\mathrm{Dd}}$ \\
$\mathrm{T} 2$ & $4.30 \pm 0.04^{\mathrm{Ad}}$ & $4.70 \pm 0.00^{\mathrm{Ab}}$ & $5.69 \pm 0.01^{\mathrm{Aa}}$ & $4.51 \pm 0.06^{\mathrm{Ac}}$ & $3.51 \pm 0.06^{\mathrm{Be}}$ \\
$\mathrm{T} 3$ & $3.92 \pm 0.03^{\mathrm{Bd}}$ & $4.47 \pm 0.02^{\mathrm{Bb}}$ & $4.65 \pm 0.03^{\mathrm{Ba}}$ & $2.95 \pm 0.05^{\mathrm{Ce}}$ & $4.05 \pm 0.06^{\mathrm{Ac}}$ \\
$\mathrm{T} 4$ & $1.72 \pm 0.02^{\mathrm{Db}}$ & $0.79 \pm 0.10^{\mathrm{Dd}}$ & $1.71 \pm 0.03^{\mathrm{Db}}$ & $1.61 \pm 0.02^{\mathrm{Dc}}$ & $3.31 \pm 0.05^{\mathrm{Ca}}$ \\
\hline
\end{tabular}

1) Treatments are the same as described in Table 1.

A-D : Means with different superscripts in the same column significantly differ at $\mathrm{p}<0.05$.

a-e : Means with different superscripts in the same row significantly differ at $\mathrm{p}<0.05$.

Table 14. Changes of Lactobacilli spp. $\left(\log _{10} \mathrm{CFU} / \mathrm{cm}^{2}\right)$ of seasoned pork during aging at $10 \pm 1^{\circ} \mathrm{C}$

\begin{tabular}{cccccc}
\hline \multirow{2}{*}{ Treatment $^{1)}$} & \multicolumn{5}{c}{ Storage(days) } \\
\cline { 2 - 6 } & 1 & 4 & 7 & 10 & 13 \\
\hline \hline $\mathrm{T} 1$ & $4.01 \pm 0.06^{\mathrm{Bd}}$ & $5.03 \pm 0.00^{\mathrm{Cc}}$ & $6.28 \pm 0.05^{\mathrm{Ca}}$ & $6.21 \pm 0.04^{\mathrm{Ba}}$ & $5.66 \pm 0.03^{\mathrm{Cb}}$ \\
$\mathrm{T} 2$ & $4.08 \pm 0.04^{\mathrm{Be}}$ & $5.68 \pm 0.03^{\mathrm{Ad}}$ & $6.92 \pm 0.01^{\mathrm{Ba}}$ & $6.28 \pm 0.07^{\mathrm{Bc}}$ & $6.77 \pm 0.02^{\mathrm{Ab}}$ \\
$\mathrm{T} 3$ & $5.16 \pm 0.05^{\mathrm{Ac}}$ & $5.15 \pm 0.10^{\mathrm{Bc}}$ & $7.15 \pm 0.00^{\mathrm{Aa}}$ & $7.09 \pm 0.00^{\mathrm{Aa}}$ & $6.46 \pm 0.01^{\mathrm{Bb}}$ \\
$\mathrm{T} 4$ & $3.45 \pm 0.04^{\mathrm{Cd}}$ & $3.71 \pm 0.03^{\mathrm{Dc}}$ & $5.70 \pm 0.02^{\mathrm{Db}}$ & $5.69 \pm 0.02^{\mathrm{Cb}}$ & $6.50 \pm 0.01^{\mathrm{Ba}}$ \\
\hline
\end{tabular}

1) Treatments are the same as described in Table 1.

A-D : Means with different superscripts in the same column significantly differ at $p<0.05$.

a-e : Means with different superscripts in the same row significantly differ at $\mathrm{p}<0.05$. 
된다. 저장기간의 경과에 따른 변화에서는 모 든 처리구가 저장 7 일까지는 유의적으로 증가 하다가 7일 이후에는 처리구 간에 뚜렷한 경향 이 없는 것으로 나타났다.

$$
\text { IV. 요 약 }
$$

한국 전통 양념 $(\mathrm{T} 1$, 간장소스; $\mathrm{T} 2$, 김치소스; $\mathrm{T} 3$, 새우젓소스; $\mathrm{T} 4$, 양파소스)을 이용하여 $10 \pm$ $1{ }^{\circ} \mathrm{C}$ 에서 13 일 동안 숙성 중 돼지고기의 물리화 학적 변화를 측정한 결과는 다음과 같다. $\mathrm{pH}$ 는 $\mathrm{T} 2$ 처리구를 제외한 모든 처리구에서 숙성기간 동안 유의적으로 감소하였다. 숙성기간 동안 염도와 당도는 증가하는 경향을 보였다. TBARS 는 저장기간이 경과함에 따라 유의적으로 증가 하였고, T4 처리구가 가장 높은 값을 나타내었 다. $\mathrm{VBN}$ 은 저장기간이 경과함에 따라 유의적 으로 증가하였다 $(\mathrm{P}<0.05)$. 보수력은 처리구 간 에 차이가 없었으며, 저장기간의 경과에 따른 변화에서도 유의적인 차이가 없었다. 전단가는 모든 처리구가 저장기간이 경과함에 따라 감소 하는 경향을 보였다. 표면 육색 중 $\mathrm{L}^{*}, \mathrm{a}^{*}, \mathrm{~b}^{*}$ 값은 저장기간이 경과함에 따라 증가하는 경향 을 보였으며, $\mathrm{a}^{*}, \mathrm{~b}^{*}$ 값은 $\mathrm{T} 2$ 처리구가 다른 처 리구에 비하여 유의적으로 높았다 $(\mathrm{P}<0.05)$. 심 부 육색 중 $\mathrm{a}^{*}, \mathrm{~b}^{*}$ 값은 $\mathrm{T} 2$ 처리구가 다른 처리 구에 비하여 유의적으로 높았다 $(\mathrm{P}<0.05)$. 가열 육에 대한 관능검사 결과, $\mathrm{T} 3$ 처리구가 모든 검사항목에서 기호도가 가장 낮게 나타났다. 총균수와 유산균수는 모든 처리구가 저장기간 이 경과함에 따라 증가하는 경향을 나타내었으 며, 대장균수는 저장기간이 경과함에 따라 뚜 렷한 경향이 없었다.

$$
\mathrm{V} \text {.사 사 }
$$

본 연구는 농림부 농림기술개발사업(2003년 과제번호 103048-1)의 지원에 의하여 이루어진 것으로, 연구비 지원에 감사를 표합니다.
VI. 인 용 문 헌

1. Brewer, M. S., Ikins, W. G. and Harbers, C. A. Z. 1992. TBA values, sensory characteristics and volatiles in ground pork during long-term frozen storage : Effects of packing. J. Food Sci. 57:558.

2. Buege, J. A. and Aust, J. D. 1978. Microsomal lipid peroxidation. Methods Enzymol. 52:302.

3. Choi, W. S. and Lee, K. T. 2002. Quality changes and shelf-life of seasoned pork with soy sauce or Kochujang during chilled storage. Korean J. Food Sci. Ani. Resour. 22:240.

4. Dierick, N., Vandekerckhove, P. and Demeyer, D. 1974. Changes in nonprotein nitrogen compounds during dry sausage ripening. J. Food Sci. 39:301.

5. Holly, R. A., Gariepy, C., Delaquis, P., Doyon, G. and Gagnon, J. 1994. Static conrtolled $\left(\mathrm{CO}_{2}\right)$ atomsphere packaging retail ready pork. J. Food Sci. 59(6):1296.

6. Kim, C. F., Jeong, J. Y., Yoo, I. J., Choi, D. Y., Lee, E. S., Lee, C. H. and Ma, K. J. 1998. Studies on the quality and shelf-life of traditional seasoned Galbi. Abstract P-108, 21th Congress of Korean Society for Food Science of Animal Resources, Seoul, Korea.

7. Kim, C. J., Su, S. K., Joo, J. H. and Cho, S. K. 1990. Pharmacological activities of flavonoids(II). Relationships of anti-inflammatory and antigranulomatous actions. Yakhak Hoeji. 34:407.

8. Lefebvre, N., Thibault, C., Charbonneau, R. and Piette, J. P. G. 1994. Improvement of shelf-life and wholesomeness of ground beef by irradiation. meat Sci. 32:371.

9. Moon, J. H., Ryu, H. S. and Lee, K. H. 1991. Effects of garic on the digestion of beef protein during storage. J. Korean Soc. Food Sci. Nutr. 20:447.

10. Paneras, E. D. and Bloukas, J. G. 1994. Vegetable oils replace pork backfat for low-fat frankfurters. J. Food Sci. 59:725.

11. SAS. 1999. SAS/STAT Software for PC. Releasw 6.11, SAS Institute, Cary, Nc, U. S. A.

12. Silvia, T. M., Miller, E. E. and Pratt, E. E. 1984. Chia seeds as a source of natural lipid antioxidant. Am. Oil. Chem. Soc. 61(5):918. 
13. Stavric, C., Matula, T. I., Klassen, R., Downie, R. H. and Wood, R. J. 1992. Effect of flavonoids on mutagenicity and bioavailability of xenobiotics in food. Am. Oil. Chem. Soc. 239.

14. Toshimitsu, H., Kazuko. S., Kawasaki, M., Munehisa, A., Shimizu, M. and Morita, N. 1988. Inhibition of cow's milk xanthine oxidase by flavonoids. J. Natural Products. 51:345.

15. Warner, R. D., Kauffman, R. G. and Russell, R. L. 1993. Quality attributes of major porcine muslces: A comparison with longissimus lumborum. Meat Sci. 33:359.

16. Zhu, L. G. and Brewer, M. S. 1998. Discoloration of fresh pork as related to muscle and display conditions. J. Food Sci. 63(5):763.

17. Zohri, A. N., Abdel-Gawad, K. and Saber, S. 1995. Antibacterial, antidermatiophytic and antioxigenic activities of onion(Allium cepa L) oil. Microbiol. Res. 150:167.

18. 高坂和久. 1975. 肉製品の鮮度保持と 測定. 食 品工業. $18,105$.

19. 柴田承二 1970 . 生理活成天然物化學. 醫齒藥出 版社. 東京. p. 425.

20. 김수민, 조영석, 성삼경, 이일구, 이신호, 김대곤. $2002 \mathrm{~b}$. 솔잎 및 녹차 추출물을 이용한 기능성 소 시지 개발. 한국축산식품학회지. 22(1):20.

21. 김철재, 김정상, 이형주, 박건영, 김종규, 경규항, 김원극, 권익부, 손동화, 이봉기, 최신양. 1999. 전통장류의 생리활성 기능: 제 1 주제(콩의 생리 활성 물질), 제 2주제(장류의 항암효과), 제 3 주 제(된장의 면역증강 물질), 제 4주제(청국장의 혈 전용해 기능), 제 5 주제(장류 중 신 색소의 기능 성). 제 2회 영남대학교 부설 장류연구소 심포지 움. 7-186.

22. 박길홍, 주진순. 1986. 새우젓 중의 단백질분해효 소에 대한 연구. 한국영양학회지, 19:363.

23. 박우문, 최원희, 유익종, 김왕준, 전기홍, 정동효.
1997. 발효식품에서 분리한 젖산균이 발효소시지 의 저장중 미생물의 특성에 미치는 영향. 한국축 산학회지, 39:60.

24. 오세욱, 김영명, 남은정, 조진호. 1997. 새우젓의 육류단백질 분해특성. 한국축산과학회지. 29:1191.

25. 이정일, 주선태, 박태선, 신택순, 하영래, 박구부. 1999. Conjugated Linoleic Acid(CLA)가 축적된 계육의 저장기간 중 이화학적 특성 변화. 한국축 산식품학회지. 19(1):88.

26. 이제룡, 정재두, 이정일, 송영민, 진상근, 김일석, 김회윤, 이진희. 2003. 뽕잎과 감잎분말 첨가가 유화형 소시지의 지방산화, 아질산염, 염기태 질 소 화합물 및 지방산 조성에 미치는 효과. 한국 축산식품학회지. 23(1):1.

27. 정승용, 이응호. 1976. 새우젓의 정미성분에 관한 연구. 한국수산학회지. 9:79.

28. 진상근, 김일석, 하경희, 허선진, 류현지, 박기훈, 배대순. 2005b. 전통양념으로 숙성하여 함기포장 한 돼지고기의 저장 중 품질변화. 한국동물자원 과학회지. 47(1):73.

29. 진상근, 김일석, 하경희, 허선진, 박기훈, 류현지, 배대순. 2005a. 전통양념으로 발효숙성하여 진공 포장한 돼지고기의 저장 중 품질 변화. 한국동물 자원과학회지. 47(1):39.

30. 진상근, 김철욱, 이상원, 송영민, 김일석, 박석규, 하경희, 배대순. 2004. 한국 전통 양념을 이용한 발효돼지고기의 품질특성. 한국동물자원과학회지. 46(2):217-226.

31. 차용준. 1995 . 전통 수산 발효 제품의 향기성분 에 관한 연구. 한국음식문화연구원논집. 6:271.

32. 최원석, 이근택. 2002. 간장과 고추장 양념 돈육 의 냉장 중 품질 변화와 저장 수명. 한국축산식 품학회지. 22:240-246.

33. 허영미. 1996. 배추김치의 항돌연변이 및 항암효 과. 부산대학교 석사학위논문.

(접수일자 : 2005. 4. 28. / 채택일자 : 2005. 8. 24.) 